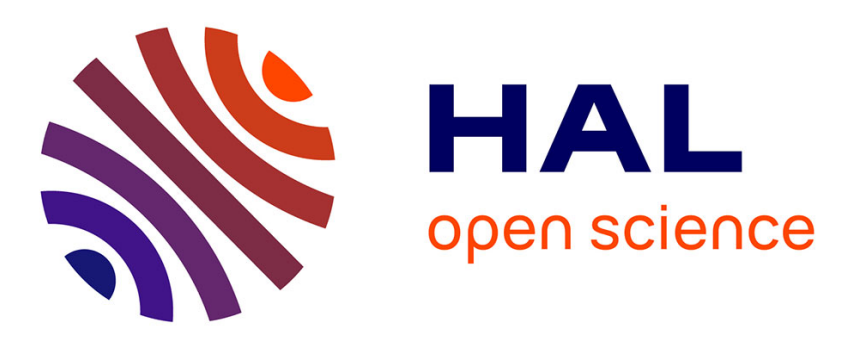

\title{
FABRICATION AND EVALUATION OF SiC/C FUNCTIONALLY GRADIENT MATERIAL
}

\author{
M. Sasaki, T. Hirai
}

\section{To cite this version:}

M. Sasaki, T. Hirai. FABRICATION AND EVALUATION OF SiC/C FUNCTIONALLY GRA-

DIENT MATERIAL. Journal de Physique IV Proceedings, 1991, 02 (C2), pp.C2-649-C2-655. 10.1051/jp4:1991278 . jpa-00249868

\section{HAL Id: jpa-00249868 https://hal.science/jpa-00249868}

Submitted on 1 Jan 1991

HAL is a multi-disciplinary open access archive for the deposit and dissemination of scientific research documents, whether they are published or not. The documents may come from teaching and research institutions in France or abroad, or from public or private research centers.
L'archive ouverte pluridisciplinaire HAL, est destinée au dépôt et à la diffusion de documents scientifiques de niveau recherche, publiés ou non, émanant des établissements d'enseignement et de recherche français ou étrangers, des laboratoires publics ou privés. 


\title{
FABRICATION AND EVALUATION OF SIC/C FUNCTIONALLY GRADIENT MATERIAL
}

\author{
M. SASAKI and T. HIRAI \\ Institute for Materials Research, Tohoku University, \\ Katahira 2-1-1, Sendai 980, Japan
}

\section{ABSTRACT}

A plate-like deposit having a compositional gradient from carbon (C) to silicon carbide (SiC) (SiC/C FGM) was obtained on a graphite substrate with chemical vapour deposition (CVD) by changing the Si/C molar ratio in input gas during deposition. Cracking due to heat flux was investigated using a $\mathrm{CO}_{2}$ laser setup. Heat flux which resulted in cracking in SiC-coated graphite (SiC NFGM) was $5.8 \mathrm{MWm}^{-2}$ at a surface temperature $\left(\mathrm{T}_{\mathrm{s}}\right.$ ) of $1300 \mathrm{~K}$ and a reverse surface temperature $\left(\mathrm{T}_{b}\right)$ of $1220 \mathrm{~K}$. In the case of $\mathrm{SiC} / \mathrm{CFGM}$, heat flux occurred cracking was $7.4 \mathrm{MWm}^{-2}$ at a $T_{s}$ of $1650 \mathrm{~K}$ and $\mathrm{a} \mathrm{T}_{\mathrm{b}}$ of $1080 \mathrm{~K}$. The temperature difference between $\mathrm{T}_{\mathrm{s}}$ and $\mathrm{T}_{\mathrm{b}}$ was $570 \mathrm{~K}$ in FGM and $80 \mathrm{~K}$ in NFGM. Thermal stress calculation showed that in cracking caused by hoop stress, the stress was close to the fracture strength of $\mathrm{SiC}$. It was clear that SiC/C FGM has effective thermal shock resistance and thermal barrier characteristics.

\section{INTRODUCTION}

In recent years, much attention has been focused on the development of high-temperature functional materials, especially in the field of aerospace applications /1\%. Functionally gradient materials (FGMs) have been developed which have a compositional or structural distribution from one side to the other side. It is necessary to have both high oxidation resistance and high fracture strength at high temperatures. We have attempted to fabricate an FGM consisting of $\mathrm{SiC}$ and $\mathrm{C}$, taking into consideration the high oxidation resistance and high fracture strength of $\mathrm{SiC}$, as well as the low Young's modulus and easy-processing of $\mathrm{C}$ /2,3/. An SiC/C FGM which has a compositional gradient from $\mathrm{C}$ to SiC has been fabricated with the CVD method by changing the $\mathrm{Si} / \mathrm{C}$ molar ratio in input gas. The fabrication and thermal properties of SiC-C composites were also investigated. The authors previously clarified the effect of the addition of $\mathrm{C}$ on the lower thermal conductivity of SiC-C composites /4/ and on the superior thermal barrier characteristics of SiC-C composites. Furthermore, they clarified the thermal barrier characteristics and thermal shock resistance of SiC/C FGM using a Xenon arc lamp heating method. As a result, it was shown experimentally and by calculation of thermal stress that SiC/C FGM has thermal barrier characteristics because of lower thermal conductivity, as well as thermal stress relaxation due to a lower Young's modulus /5-7/. 
The authors have already investigated the thermal shock resistance of $\mathrm{SiC} / \mathrm{CFGM}$ using the $\mathrm{CO}_{2}$ laser (50 W) method $/ 8,9 /$. However, the difference between SiC-single-layer-coated graphite (SiC NFGM) and $\mathrm{SiC} / \mathrm{C} \mathrm{FGM}$ was not clarified of the lower laser power $(50 \mathrm{~W})$ of this method. In the present study, we report the thermal shock resistance of SiC/C FGM having a graphite substrate (30 mm in diameter, $5 \mathrm{~mm}$ in thickness) using the $5 \mathrm{~kW}-\mathrm{CO}_{2}$-laser-heating method, and the effect of laser spot diameter.

\section{EXPERIMENTAL}

$\mathrm{An} \mathrm{SiCl}_{4}-\mathrm{CH}_{4}-\mathrm{H}_{2}$ system was used for the preparation of the $\mathrm{SiC}$ NFGM and $\mathrm{SiC} / \mathrm{C} \mathrm{FGMs.} \mathrm{The}$ temperature of the $\mathrm{SiCl}_{4}$ reservoir was kept at $293 \mathrm{~K}$, and $\mathrm{SiCl}_{4}$ gas was carried into the reactor by bubbling of hydrogen gas. The flow rate of hydrogen gas and $\mathrm{SiCl}_{4}$ gas was $5.0 \times 10^{-6} \mathrm{~m}^{3} \mathrm{~s}^{-1}$ and $1.7 \times 10^{-6} \mathrm{~m}^{3} \mathrm{~s}^{-1}$, respectively. The flow rate of $\mathrm{CH}_{4}$ gas was continuously changed from $6.7 \times 10^{-6}$ to $1.3 \times 10^{-6} \mathrm{~m}^{3} \mathrm{~s}^{-1}$. The gas flow rates were controlled by a programmable controller. The deposition temperature was $1673 \mathrm{~K}$, and total gas pressure was $6.5 \mathrm{kPa}$. A compositional distribution in the depth direction of the SiC/C FGM was investigated by EPMA equipment. Specimens thus fabricated were irradiated by $50 \mathrm{~W}$ - and $5 \mathrm{~kW}-\mathrm{CO}_{2}$ laser in air and evaluated as to thermal shock resistance.

\section{RESULTS AND DISCUSSION}

$\mathrm{SiC} / \mathrm{C} \mathrm{FGMs}$ were fabricated on graphite substrates ( $30 \mathrm{~mm}$ in diameter, $5 \mathrm{~mm}$ in thickness). Figure 1 shows a continuously changed composition of $\mathrm{Si}$ in a specimen having an $\mathrm{SiC} / \mathrm{C}$ graded layer with a thickness of $1.8 \mathrm{~mm}$. Other SiC/C FGMs having thicknesses of $0.8 \mathrm{~mm}$ and $2.1 \mathrm{~mm}$ and SiC NFGM having a 0.3 $\mathrm{mm} \mathrm{SiC} \mathrm{layer} \mathrm{were} \mathrm{fabricated.} \mathrm{Figure} 2$ illustrates the laser heating setup $\left(\mathrm{CO}_{2}\right.$ laser, Mitsubishi; ML50C) used for the thermal shock resistance test. The difference of thermal shock resistance between $\mathrm{SiC}$

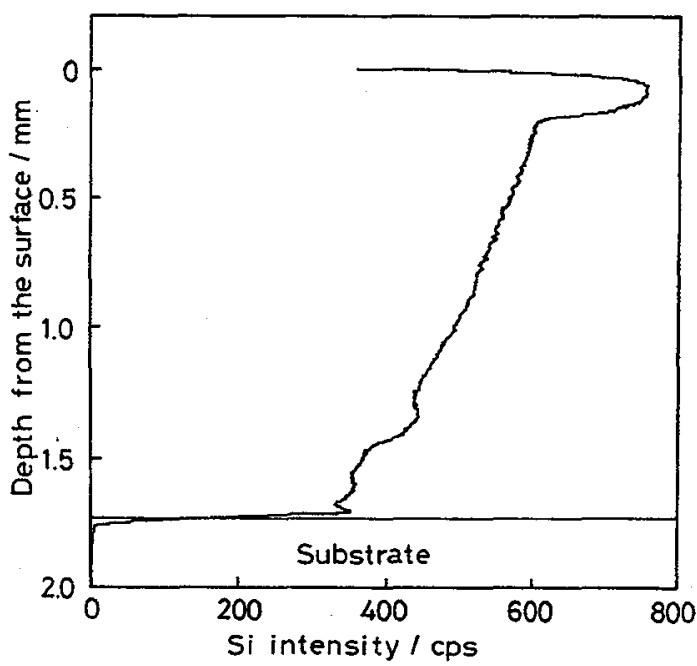

Fig. 1. Compositional distribution of SiC/C FGM prepared at a $T_{\text {dep }}$ of $1673 \mathrm{~K}$ and a $P_{\text {tot }}$ of $1.3 \mathrm{kPa}$.

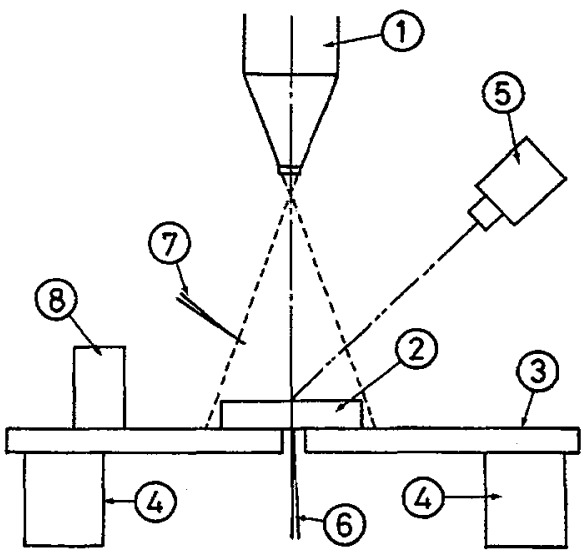

Fig. 2. Schematic diagram of laser heating setup. (1) $\mathrm{CO}_{2}$ laser, (2)specimen, (3)stainless steel, (4)firebrick, (5)radiation thermometer,

(6)thermocouple $(0.2 \mathrm{~mm}$ in diameter), (7)thermocouple for laser trigger, (8)AE sensor. 
NFGM and SiC/C FGM because of lower laser power (50W) was clarified. The square of AE peak height substituted for the area of AE signal as an AE energy. AE energy obtained by $50 \mathrm{~W}$-laser heating is shown in Fig. 3, and SEM photographs of the heated surfaces of the specimens are shown in Fig. 4. No cracks were observed in either specimen. AE energy was very low, being equal to the noise level. The results show the high thermal shock resistance of SiC film.

Other thermal shock tests, therefore, were conducted on some specimens using a $5 \mathrm{~kW}-\mathrm{CO}_{2}$ laser. Figure 5 demonstrates the relationship between laser power density, laser spot diameter and cracking. With an increase in laser spot diameter above $25 \mathrm{~mm}$, the heating situation was close to the overall heating of the specimen ( $30 \mathrm{~mm}$ in diameter). The critical laser power density shows other thermal shock resistance characteristics of the materials. This result demonstrates the high thermal shock resistance of SiC NFGM and $\mathrm{SiC} / \mathrm{C}$ FGM compared with $\mathrm{Al}_{2} \mathrm{O}_{3}$, Macor and $\mathrm{ZrO}_{2}-\mathrm{NiCrAlY}$-coated stainless steel (SUS304) FGM. Compared with the critical laser power density of SiC NFGM and SiC/C FGM, SiC/C FGM has thermal shock resistance superior to that of SiC NFGM.

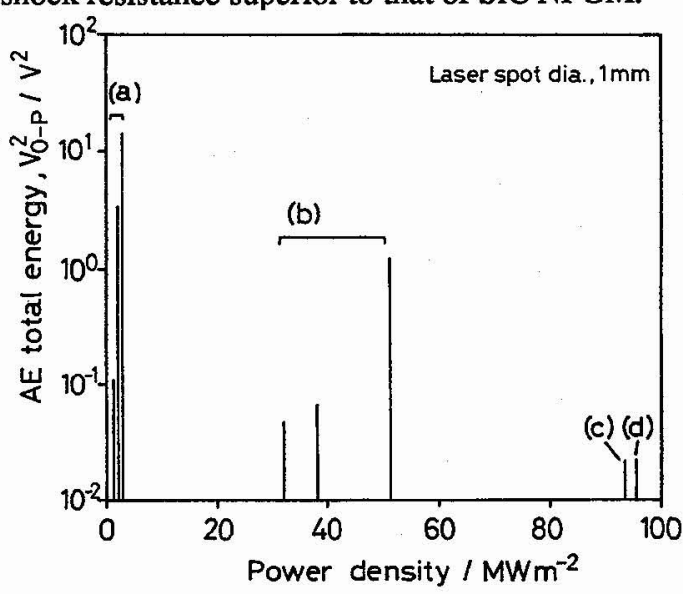

Fig. 3. Relationship between AE total energy and laser power density in the laser spot diameter of $1 \mathrm{~mm}$.

(a), sintered- $\mathrm{ZrO}_{2}\left(\mathrm{Y}_{2} \mathrm{O}_{3}\right)$; (b),plasma sprayed- $\mathrm{ZrO}_{2}$ ' NiCrAlY/Cu FGM; (c),CVD-SiC(SiC NFGM) and (d), SiC/C FGM.

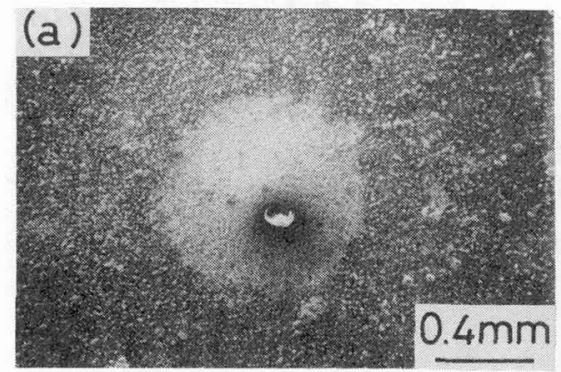

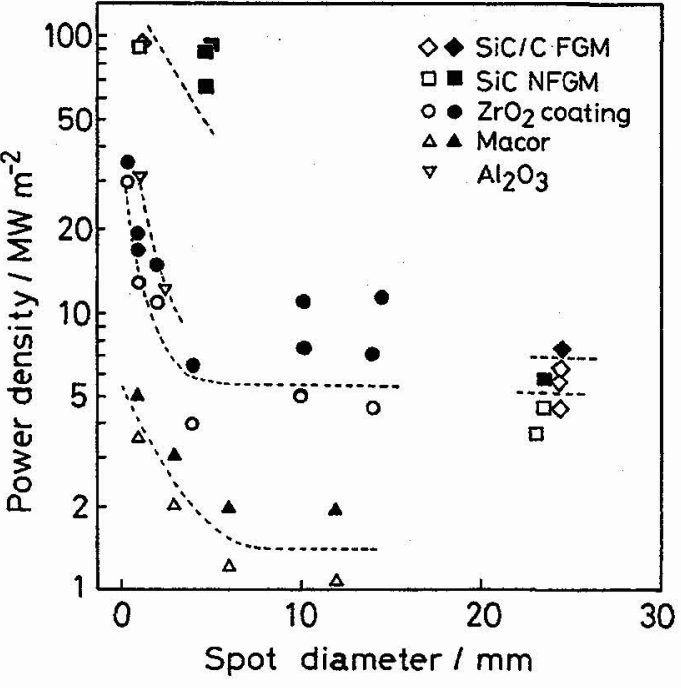

Fig. 5. Relationship between laser power density and spot diameter.

open circle, no cracking; closed circle, cracking

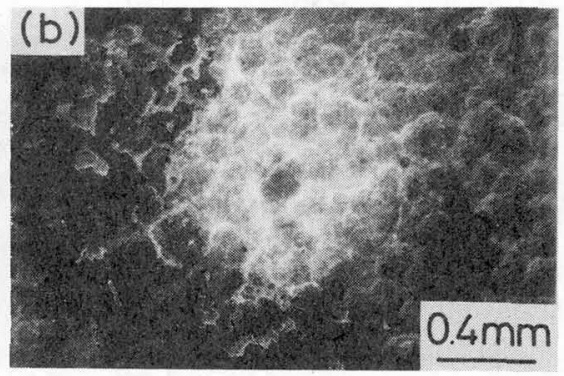

Fig. 4. SEM photographs of the surface of (a);SiC NFGM and (b);SiC/C FGM after the irradiation of laser in the diameter of $1 \mathrm{~mm}$. 
Figure 6 shows the relationship between laser power density and the temperature difference of the heated and reverse sides. In the case of SiC NFGM, cracking causedbylaser power density was $5.8 \mathrm{MWm}^{-2}$, and was $7.4 \mathrm{MWm}^{-2}$ in SiC/C FGM. Increasing the thickness of the coated layer from $0.8 \mathrm{~mm}$ to $1.8 \mathrm{~mm}$ caused the temperature difference in SiC/C FGM to increase from 390 to $560 \mathrm{~K}$. Heat flux caused cracking was 7.4 $\mathrm{MWm}^{-2}$ in both $\mathrm{SiC} / \mathrm{C}$ FGMs. Results of local heating test without cracking for the specimen of 30 $\mathrm{mm}$ in diameter are shown in Table I. Figure 7 demonstrates the relationship between laser power density and the calculated surface temperature of the specimen. Cracking occurred on the SiC NFGM at a temperature of $1270 \mathrm{~K}$. However, no cracking occurred on the SiC/C FGM with a film thickness of $1.8 \mathrm{~mm}$ at a surface temperature of $1500 \mathrm{~K}$. Figure 8 shows the cracking in the specimens after laser irradiation. Cracks were observed around the specimens in both SiC NFGM and SiC/C FGM. SEM photographs of the sur-

Table I. Results of local heating test without cracking for the specimen of $30 \mathrm{~mm}$ in diameter.

\begin{tabular}{lrrr}
\hline \multicolumn{1}{c}{ Parameter } & SiC NFGM & \multicolumn{2}{c}{ SiC/C FGM } \\
\hline Surface temperature (K) & 1060 & 1510 & 1450 \\
Reverse side temperature (K) & 1000 & 1170 & 970 \\
Temperature difference (K) & 60 & 340 & 480 \\
Film thickness (mm) & 0.3 & 0.8 & 1.8 \\
Heat flux (MWm $\left.{ }^{-2}\right)$ & 4.6 & 6.4 & 6.4 \\
Laser spot diameter $(\mathrm{mm})$ & 23.5 & 24.5 & 24.5 \\
\hline
\end{tabular}

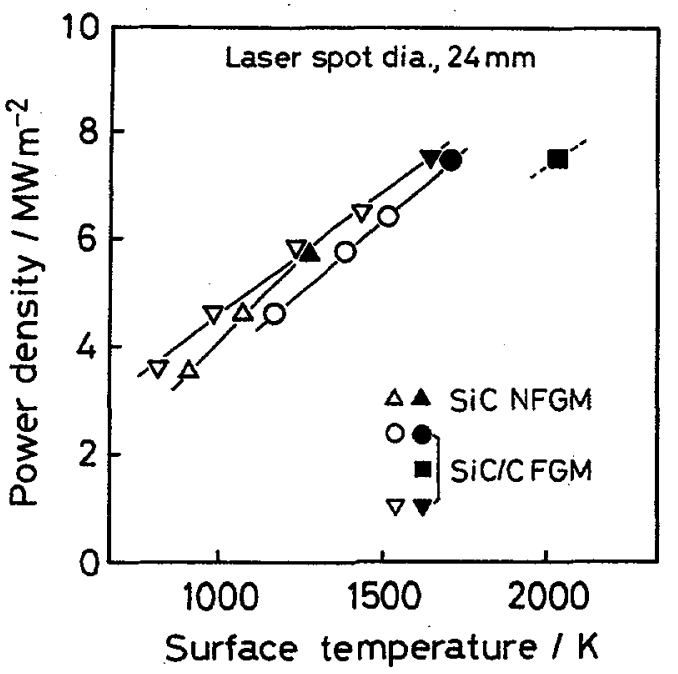

Fig. 7. Relationship between laser power density and surface temperature under thermal shock resistance test in the film thickness of $\Delta 0.3, \boldsymbol{\varphi 0 . 8}, \nabla 1.8$ and $2.0 \mathrm{in} \mathrm{mm}$. open circle, no cracking; closed circle, cracking

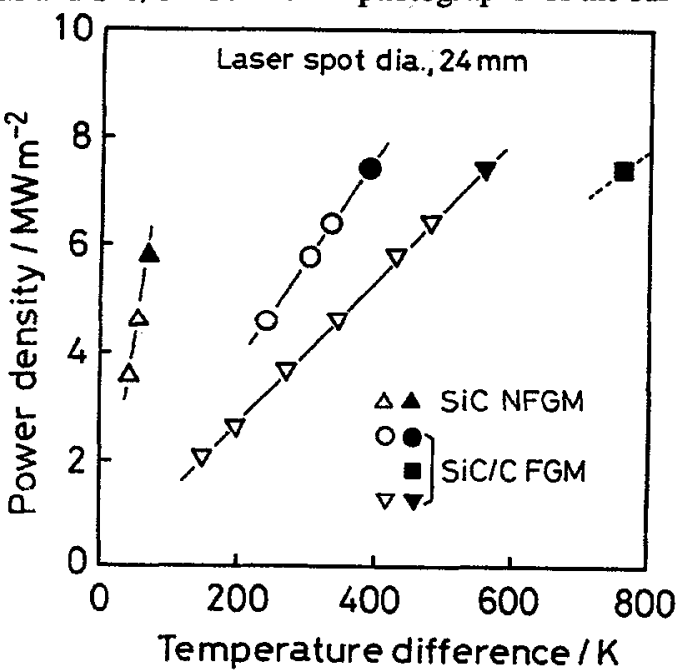

Fig. 6. Relationship between laser power density and temperature difference under thermal shock resistance test in the film thickness of $\Delta 0.3,00.8$, $\nabla 1.8$ and 2.0 in $\mathrm{mm}$. open circle, no cracking; closed circle, cracking

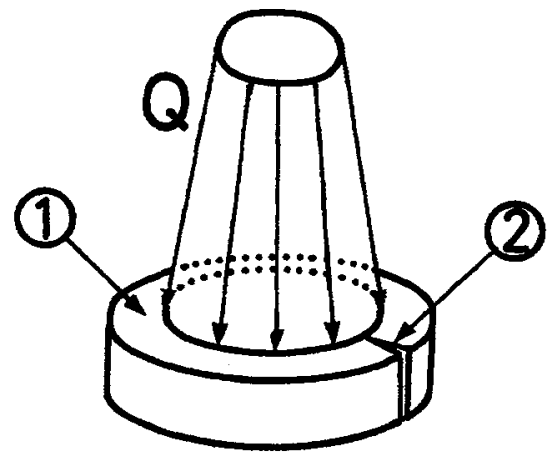

Fig. 8. Schematic diagram of the cracking in specimen under local heating.(1)specimens (SiC NFGM and SiC/C FGM), (2)crack 
faces of laser-irradiated $\mathrm{SiC}$ NFGM and SiC/C FGM are shown in Fig. 9. Figure 9(a) shows a crack on the SiC NFGM with a film thickness of $0.3 \mathrm{~mm}$ and a heat flux of $5.8 \mathrm{MWm}^{-2}$. In this case, the reverse surface temperature was $1220 \mathrm{~K}$, and the calculated surface temperature was $1300 \mathrm{~K}$. Figure 9(b) shows a crack on the SiC/C FGM with a film thickness of 1.8 $\mathrm{mm}$ and a heat flux of $7.4 \mathrm{MWm}^{-2}$. In both cases, cracks run through the SiC grains. These SEM photographs show that the cracks occurred due to similar fracture stress modes. The reverse surface temperature of $\mathrm{SiC} / \mathrm{C} \mathrm{FGM}$ was $1080 \mathrm{~K}$, and the calculated surface temperature was $1650 \mathrm{~K}$.

For the purpose of investigating crack formation, non-steady state thermal stress analysis was attempted. Heat flux was fixed at $3.6 \mathrm{MWm}^{-2}$, in which no cracking occurred in either SiC NFGM nor SiC/C FGM. Thermal stress on the surface of the specimens at 1 second after laser irradiation was calculated. As shown in Fig. 10, surface axial stress is close to zero in both cases of SiC NFGM and SiC/C FGM. The SiC layer or the SiC/C FGM layer did not detach from the graphite substrate supported by the lower axial stress. Axial stress in the depth direction was also close to zero. Such absence of detachment was thought to be due to the lower difference in thermal expansion coefficients between films and the substrate. Figure 11 demonstrates the radial stress on the surface of the specimens under laser heating. The radial stress on the surface of the specimens is compressive, and the radial stress is maximum on the surface. The maximum radial stress of SiC NFGM is $500 \mathrm{MPa}$ close to the fracture stress of $\mathrm{SiC}$, of which $\mathrm{SiC} / \mathrm{C} \mathrm{FGM}$ is $220 \mathrm{MPa}$ lower than that of SiC NFGM. Calculation of radial stress showed the compressiveness extending over the whole specimen.

Figure 12 demonstrates the hoop stress on the surface of the specimens. This figure shows that the hoop stress in the part which was not heated by laser is tensile. The hoop tensile stress is maximum on the
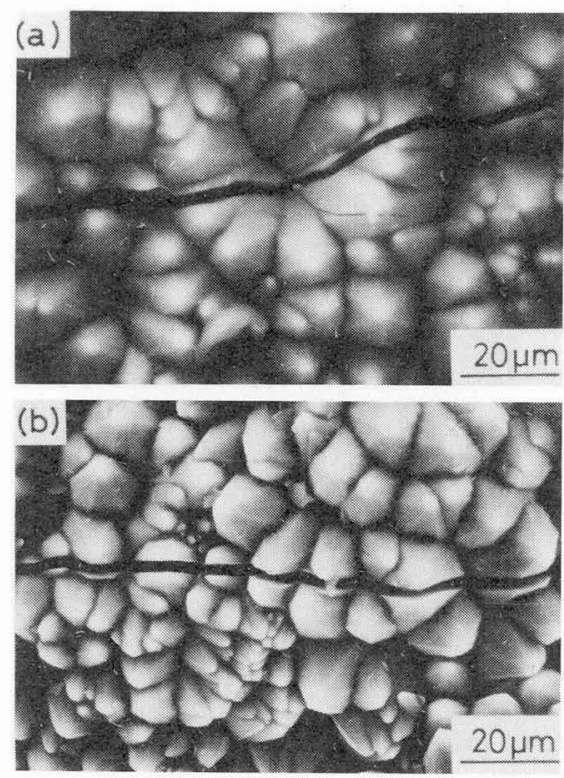

Fig. 9. SEM photographs of the crack on the heated surface of specimen

(a) SiC NFGM (heat flux, 5.8 $\mathrm{MWm}^{-2}$ )

(b)SiC/C FGM (heat flux, 7.4 $\mathrm{MWm}^{-2}$ )

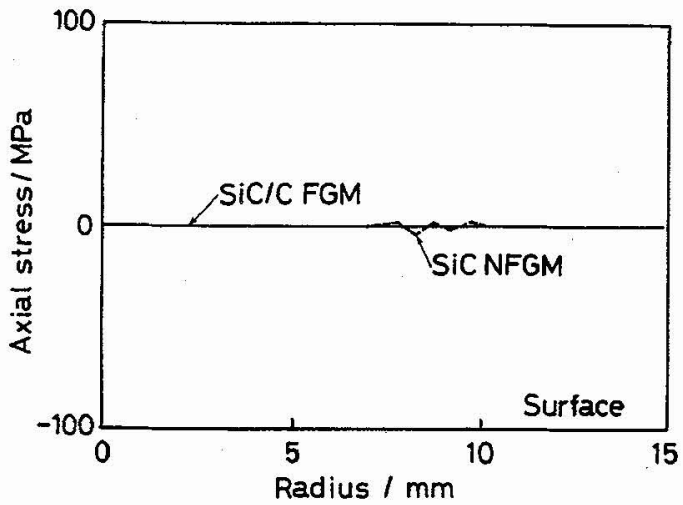

Fig. 10. Calculated axial stress on the surface of $\mathrm{SiC}$ NFGMand SiC/C FGM at a heat flux of $3.6 \mathrm{MWm}^{-2}$. 


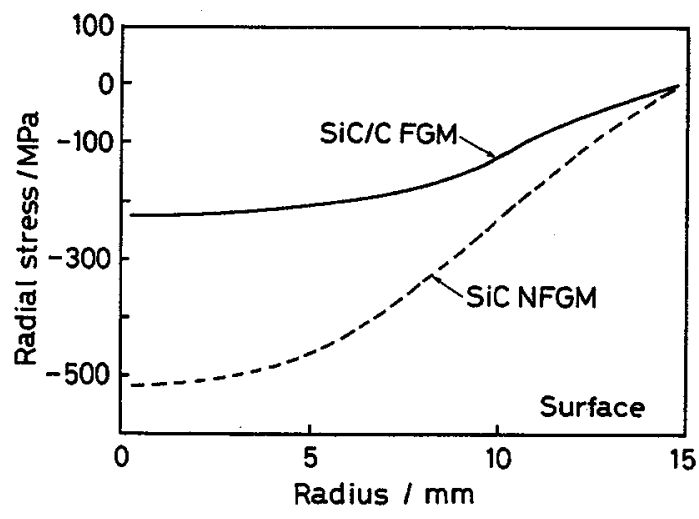

Fig. 11. Calculated radial stress on the surface of SiC NFGM and SiC/C FGM at a heat flux of 3.6 $\mathrm{MWm}^{-2}$.

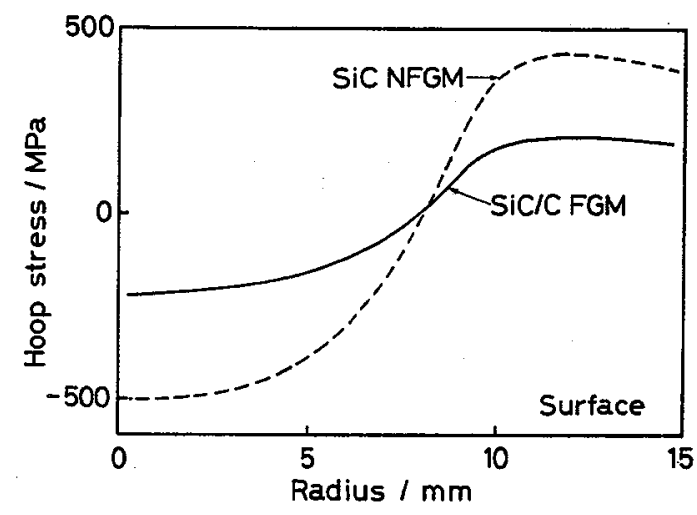

Fig. 12. Calculated hoop stress on the surface of $\mathrm{SiC}$ NFGM andSiC/C FGM at a heat flux of $3.6 \mathrm{MWm}^{-2}$.

surface of the specimens. SiC NFGM has a higher hoop tensile stress close to the fracture strength of $\mathrm{SiC}$ (650MPa). Cracking around SiC NFGM at a heat flux of $5.8 \mathrm{MWm}^{-2}$ was thought to be due to the outer hoop tensile stress caused by local heating. Cracking around SiC/C FGM at a heat flux of $7.4 \mathrm{MWm}^{-2}$ was also caused by similar hoop tensile stress.

A thermal shock resistance test using laser heating was previously reported for a $\mathrm{ZrO}_{2}\left(8 \% \mathrm{Y}_{2} \mathrm{O}_{3}\right) /$ NiCrAlY/SUS304 FGM/10-12/. Calculation showed biaxial compressive stress in the heated part of $\mathrm{ZrO}_{2} /$ NiCrAlY/SUS304 FGM. It is expected that non-elastic deformation of $\mathrm{ZrO}_{2}$ occurred in the heated part, and the tensile stress appeared in the some parts of $\mathrm{ZrO}_{2}$ after cooling. Cracking of $\mathrm{ZrO}_{2}$ film was thought to be due to tensile stress accompanying this non-elastic deformation $/ 10 /$. In contrast to $\mathrm{ZrO}_{2} / \mathrm{NiCrAlY} /$ SUS304 FGM, SiC/C FGM does not suffer cracking in the heated part, and cracking occurs due to hoop tensile stress in the outer portion of the specimens. These results and calculations show that the SiC/C FGM suffers cracking under local heating.

As mentioned above, it is clear that SiC/C FGM has both effective thermal shock resistance and thermal barrier characteristics under local heating.

\section{CONCLUSIONS}

A plate-like deposit having a compositional gradient from $\mathrm{C}$ to $\mathrm{SiC}$ was obtained on a graphite substrate (30 mm dia. $\times 5 \mathrm{~mm}$ thick) using an $\mathrm{SiCl}_{4}-\mathrm{CH}_{4}-\mathrm{H}_{2}$ gas system by changing the $\mathrm{Si} / \mathrm{C}$ molar ratio in input gas. Heat flux of $5.8 \mathrm{MWm}^{-2}$ caused cracking in SiC NFGM (SiC-coated graphite) and $7.4 \mathrm{MWm}^{-2}$ in $\mathrm{SiC} / \mathrm{C} \mathrm{FGM}$ (SiC/C FGM-coated graphite). Increasing the thickness of the SiC/C FGM layer from $0.8 \mathrm{~mm}$ to $1.8 \mathrm{~mm}$ caused the temperature difference between the surface and the reverse surface of the SiC/C FGM to increase from 390 to $560 \mathrm{~K}$. Laser power density of $7.4 \mathrm{MWm}^{-2}$ caused cracking in several types of $\mathrm{SiC} /$ C FGM. SiC/C FGM which contained C dispersion in the CVD layer had both effective thermal shock resistance and thermal barrier characteristics. 
Acknowledgment

The authors wish to thank Drs. T. Hashida and H. Takahashi for their help in conducting the laser heating tests and thermal stress calculations.

\section{REFERENCES}

/1/ NIINO M., HIRAI T. and WATANABE R., J. Jpn. Composites Mat., 13(1987)257.

/2/ SASAKI M., WANG Y., HIRANO T. and HIRAI T., J. Ceram. Soc. Jpn., 97(1989)539.

/3/ UEMURA S., SOHDA Y., KUDE Y., HIRAI T. and SASAKI M., J. Jpn. Soc. Powder and Powder Met., 37(1990)275.

14/ WANG Y., SASAKI M. and HIRAI T., J. Jpn. Soc. Powder and Powder Met., 37(1990)267.

/5/ NIINO M., KUMAKAWA A. and SASAKI M., J. IEE Japan, 110(1990)35.

/6/ KUMAKAWA A., MAEDA S., SASAKI M., NIINO M., SAKAMOTO A., SASAKI M. and HIRAI T., Proc. European Space Agency Symp. (ESA SP-303, June 1990)339.

7// SASAKI M. and HIRAI T., Proc. 1st Int. Symp. Functionally Gradient Materials, eds. M. Yamanouchi, M. Koizumi, T. Hirai and I. Shiota, (1990)231.

/8/ SASAKI M., YANG Y., OHKUBO A. HASHIDA T., HIRAI T. and TAKAHASHI H., J. Jpn. Soc. Powder and Powder Met., 37(1990)271.

19/ SASAKI M., HIRAI T., HASHIDA T. and TAKAHASHI H., J. Jpn. Soc. Powder and Powder Met., 37(1990)966.

/10/ HASHIDA T., TAKAHASHI H. and MIYAWAKI K., J. Jpn. Soc. Powder and Powder Met., 37(1990)307.

/11/ MIYAWAKI K., HASHIDA T. and TAKAHASHI H., J. Jpn. Soc. Powder and Powder Met., 37(1990)457.

/12/ HASHIDA T. and TAKAHASHI H., Proc. 1st Int. Symp. Functionally Gradient Materials, eds. M. Yamanouchi, M. Koizumi, T. Hirai and I. Shiota, (1990) 365. 